\title{
The development of students' adversity quotient through online learning models: A case study of an Islamic education course
}

\author{
Dina Mardiana a,", Tobroni ${ }^{\mathrm{a}}$, Triyo Supriyatno ${ }^{\mathrm{b}}$ \\ ${ }^{a}$ Faculty of Islamic Studies-University of Muhammadiyah Malang, Malang 65151, Indonesia \\ ${ }^{\mathrm{b}}$ Faculty of Tarbiyah and Teacher Training, Maulana Maliki Islamic State University of Malang, Malang 65144, Indonesia
}

Article history:

Received: 28 April 2021 / Received in revised form: 25 June 2021 / Accepted: 27 June 2021

\begin{abstract}
Students' Adversity Quotient is one of the most significant elements in online education. This research focused on analyzing how the design of learning of an online Islamic education course called Pendidikan Agama Islam (PAI) prepared the development of students' adversity quotient. This research was located at a university in Malang, Indonesia and its methodology used qualitative case study. Based on Stoltz's Adversity Quotient theory (Stoltz, 1997), data collection for this study was carried out through online-based interviews, participant observation, and documentation. However, interactive model of Miles, Huberman, and Saldana (Miles, et al., 2014) was used as data analysis. The research found that the PAI course at a university in Malang had a theoretical learning model, which could develop students' adversity quotient. The theoretical learning model of PAI requires an ability to adapt cognitive structures through the stages of assimilation, accommodation, and equilibration of new knowledge, as well as psychic readiness to face challenges providing the development of students' adversity quotient. This theoretical learning model facilitated the development of students' adversity quotient, as emerged through four indicators: resilient, persistent, sincere, and self-gratefulness. The contribution of this research is crucial to the implementation of online Islamic education learning through a theoretical learning model that will lead to benefits in achieving educational targets more effectively.
\end{abstract}

Keywords: adversity quotient; Stoltz theory; online learning; cognitive psychology; Islamic education course

\section{Introduction}

The intricacies of online learning deviances at the level of higher education needs to be reacted to positively by each college to be able to grow up an excellent graduate, as done by some countries such as Florida, American state (Waschull, 2018) or Finland (Härkki, T., Vartiainen, H., SeitamaaHakkarainen, P., \& Hakkarainen, 2021). One of these deviances is the development of students' adversity quotient through various implementation efforts in the form of innovative learning models as well as theoretical elements through the learning methods used. Normally, there is an empirical consequence of these efforts to boost students' adversity quotient, which is connected with the design of online learning at the higher education, as argued by Loeffler, et al. (Loeffler, et al., 2019), Shan Li, et al. (Li, et al., 2020), Carter, et al. (Carter et al., 2020), or Hooshyar, et al. (Hooshyar et al., 2020). In main context of framework, this effort is a real form of increasing the quality of university graduates who ar e prospected to have behavior, metacognition readiness, as well as encouragement to face the stride of online learning technology while still referring to the scientific principles they

\footnotetext{
* Corresponding author.
}

Email: dinamardiana@umm.ac.id

https://doi.org/10.21924/chss.1.1.2021.10 practice.

In Malang City, East Java, there is a university, which is determined in the philosophical spirit of Life-Based Learning. Interestingly, this college has been able to strengthen its online learning design as well as its achievements in the element of managing online learning at the higher education, by the consistency of implementing its online learning quality (Jureynolds \& Ying, 2020). This phenomenon is espoused by the progressive role of this university in positioning itself as a technopreneur competence for academicians through the development of effective educational learning strategies and models to be able to grow up the competent graduates.

In a global scope, the pattern of linking graduate competence and educational strategy development has been scientifically studied from any multi-disciplinary backgrounds, started from the level of the educational unit (Mulianti, et al., 2018), the perspectives of the curriculum design (Rachmawati, 2018), to the model of learning used (Adriyanto et al, 2020). As Wardani stated, (Wardani, 2019) there is a significant and positive relationship between online learning design and adversity quotient, so that these two variables are the elements that establish the online learning effectiveness. Furthermore, the study of the development of student abilities in terms of adversity quotient is an important aspect for its university in reaching the learning goals.

On the other side, the perspective of adversity quotient 
theory (Stoltz, 1997), especially indicators of adversity quotient views a relationship between self-regulation and metacognition that forms a bond between motivation and self-awareness in form of action (Dinsmore et al., 2008). An ability to improve this adversity quotient is one of the indicators of the ability to control one's cognition, behavior, and motivation in achieving certain goals (Wolters, et al., 2005), and could provide a resilient attitude (Dorji \& Singh, 2019). In fact, the potential of these attitude has existed in each individual as a fitrah given by God and is able to grow up optimally if trained and optimized. Based on these theoretical framework, PAI course at the higher education level becomes the right gap in effort to boost students' adversity quotient. The reason is that PAI course at the higher education commonly has a role in developing students to have a noble behavior based on the religious beliefs. Meanwhile, this research assumed that the development of students' adversity quotient through online learning models can be observed, analyzed, and interpreted in depth through the PAI course implemented at the university.

Furthermore, this article intends to analyze and interpret the meaning behind the online PAI course learning model applied at a university in Malang City so that students can develop their adversity quotient. Through this analysis, it is expected that this study will be able to provide the technical-didactic aspect of online Islamic education, especially in the term of its theoretical learning model. As a result, in the end of learning process, it will lead to benefits in progressing educational goals more effectively.

\section{Methodology}

This study focused on developing students' adversity quotient through the online PAI course model implemented by a university in Malang. Therefore, this study used a qualitative approach attempting to explore how the theoretical learning model of an online PAI course improves the development of students' adversity quotient. Thus, in this context, the researcher used a type of case study research that aimed to understand this phenomenon more deeply. The PAI course in this research had two credits with the majority online learning portion in its PAI learning process with the assessment type derived from written tests, assignments, and social projects. The informants in this study were taken through a purposive technique with a total of 52 students from the Faculty of Business Creation, the Faculty of Informatics Engineering, the Faculty of Public Relations, and the Faculty of Computer Science at this university. The researcher in this study had a position as a main instrument whose presence aimed to create a good relationship with the informants on the site of research.

Due to the large-scale social restrictions (PSBB) policy during the COVID-19 pandemic, data collection of this research was carried out through online-based interviews and observations. The sources of documentation were obtained from students' academic grade lists of PAI course, the video of PAI course learning, and PAI course academic archives in its university. Interviews were conducted with 52 students who were selected based on two criteria, namely currently taking the PAI course at its university and active students' class of 2020/2021. Data collection was ended when the data were seen complete. This means that all research focus has been described comprehensively.

For data analysis, the researcher referred to the interactive cycle model initiated by Miles, Huberman, and Saldana (Miles et al., 2014) through the stages of data collection, condensation, presentation, and data verification. After all of data have been collected, the data were simplified, sorted, transformed, or abstracted to make it close to the clear section of the written notes, transcript interviews, documents, and other important materials. This is called condensation stage. The results from multi-access data sources were triangulated by method and source triangulation techniques. The data validation was obtained through research Forum Group Discussion (FGD), extension of observation, and member check. On the other hand, data reliability was carried out through an internal confirmability test from the expert of PAI course.

\subsection{Learning model of PAI course at a university in Malang}

In the university's guideline document for curriculum development in 2018, it is explained that the capability-based curriculum (Law of Indonesia Republic Number 20 of 2003 on National Education System, 2003) is the normative foundation of its university, which is developed through several principles, one of which is to develop students' agility and adaptability to the dynamics of progress in science and technology. This statement means that the spirit of theoretical learning model that is provided by its university is a part of the objectives of developing student capabilities, which are designed in these two elements (i.e. the ability to adapt cognitive structures and psychic readiness to face challenges). Therefore, theoretical learning model is needed by translating the normative foundation of its university into a more concrete pedagogical level. Indeed, the hierarchy of structures of learning process requires an integrated connectivity between its elements, beginning from the learning stage that refers to the normative foundation of the university to the most practical hierarchy in the term of learning implementation carried out by a lecturer. It is common if the form of the whole cycles between these elements in the downstream will be able to have a positive influence on the practical dimension of developing students adversity quotient towards the formation of mature human beings who can response and face the challenges of the increasingly speedy technological period.

As a consequence, theoretical learning model carried out at the university always refers to the efforts to improve two models of student activities as described above. The students' ability to adapt cognitive structures through the stages of assimilation, accommodation, and equilibration of new knowledge from PAI course and exploit change (i.e. cognitive development) and students' psychic readiness to face challenges (i.e. adaptability) are two entities that indirectly needs the good adversity quotient of the students (Stoltz, 1997). Adversity readiness is shown through actions that encourage an individual to response, explore, and adapt a new knowledge acquired during the learning process (Landrum, B., Bannister, J., Garza, G., \& Rhame, 2020). In the term of online learning systems that are directly linked with the implementation of virtual-based learning technology, it requires readiness to adapt in the type of learning behavior from students (Abuhassna, et al., 2020). Next, readiness in the pace challenges of PAI course aspect is marked by the emergence of feelings (affective) as well as reactions to achieve the learning goals (Vinas \& Aquino-Malabanan, 2015). This readiness becomes the "motor" to guide students' adversity quotient enabling them to 
reach their learning targets and objectives. Furthermore, the adaptability of psychic readiness can be improved through theoretical learning models that support students to be capable of responding any problems well, keeping on focus, and thinking hard so that they can find certain strategies to solve any problems encountered in the learning process. It is similar with Louca's idea (Louca, 2003) emphasizing metacognition in a person's ability to acquire knowledge with one's awareness during learning activities (Asy'ari, et al., 2018).

Next analysis from this description is about the stage leading theoretical learning model to its position as the important interrelated aspects and to develop the achievement of learning goals (Engin, 2017). Theoretical learning model is an urgent design needed in current pandemic situation, so the challenges of online learning in all aspects must be faced by students to achieve the expected learning goals. In this situation, students' adversity quotient becomes important for students to have.

In fact, the theoretical learning model conducted at this university has three interconnected stages, i.e. assimilation, accommodation, and equilibration based on online learning. The three stages are carried out during the learning process of PAI course by utilizing information and communication technology.

The selection of online Islamic education learning models encourages the formulation of the course learning process that is adapted to the academic guidelines of the university. The provisions set by this university linking to the online learning system regulate the creativity and flexibility aspects of the lecturers during the learning process. The activities of online course are carried out with a minimum requirement of $80 \%$ of the total number of meetings in one semester. By so doing, for a semester period, online Islamic education learning can be done through two forms of learning design of platform, namely asynchronous and synchronous. The asynchronous online learning is a learning format in an independent learning situation and it is carried out at different times through quizzes, link room media, assignments, and discussion forums; while the synchronous platform allows a learning to be carried out at the same time through video conferences or webinars.

As a forum to accommodate these two learning platforms, the system of online learning at this university is centered on one Learning Management System (LMS). Learning services that can be found in this link include learning systems in blended learning, offline and online learning formats. The three formats that have been facilitated can be used flexibly by lecturers. In other words, the curriculum policy, which has provided flexibility for the lecturers to develop their learning creativity has been provided through an integrated system that can facilitate any different online learning features. One of the lecturers in the Islamic education subject in this context stated:

"We have a BGA curriculum design, which one of its contents is also a foothold for the implementation of Islamic education learning on our campus. To maintain the quality and responsiveness of the curriculum, we continuously conduct the quality assurance tests of the curriculum every year. One concrete form of our efforts is by setting a minimum standard of $B$ grade that must be achieved by our students in three general courses, namely Pancasila, Citizenship, and Islamic education itself".

Through the interview, the role of lecturers has been in line with the teaching pattern of PAI course. Thus, the theoretical learning model of PAI course is designed by theoretical lectures in the classroom and practical activities in the field, both of which can be included in the LMS system. Interestingly, concerning with the development of the psychomotor aspects of students, PAI course is designed as a learning process that seeks to improve student's abilities in the practice of making a good relationship with the society in the model called as "social project". This learning stage consequently requires the students to interact and gain a new knowledge from the wider community.

Based on the results of interviews to 52 students as research informants, it was concluded that the most prominent role of the community from the academic activities is the social project activities. Students are required to find the learning partners and to have good student interpersonal relationships. The participant observation of researcher showed that interaction between students and their "social project" partner is what ultimately forces students to want to learn and upgrade their self-gratefulness, as revealed by one of the lecturers:

"The priority of social project activities in our Islamic education course lies in an active interaction between students, so it can improve the students' gratefulness of themselves. On the other side, we hope that with this social project, students are encouraged to learn and improve the quality of their interpersonal relationship".

In the researcher observation, this kind of interactive pattern is a real form of life-based learning. Thus, the theoretical learning model in this course needs the readiness of students to want to socialize with learning environments outside themselves. It then can be stated that the acquisition of the learning dimensions (good habituation) of this university's students is based on the experiences they get in.

Technically, social project is a form of Islamic education course assignment at the end of the semester. The results of documentation obtained by the university, social projects conducted by students in groups are contained in the form of posters or pamphlets themed on tolerance between religious communities. While in terms of knowledge, Islamic education course in this university focuses on a good understanding of the meaning of religion and faith in the context of the real world. Students are helped to digest and explore the Islamic education course's material so that it is able to faith in an inclusive, open, plural, but still in the rational-critical corridor, as one of the student informants told the researchers:

"We learned Islamic education course conditioned to be in a forum with some different ideology backgrounds. So, we are Muslims for example, discussing religious material in accordance with our text book, along with colleagues who are other ideologist as well. In some of the discussions we have had, sometimes there are differences in concepts that we believe in our respective ideology. But, precisely from the different, we came to understand the concept of the understanding of each ideology".

Thus, there is a mutually supportive relationship between student cognitive development factors and their adaptability through "social projects" that ultimately develop students' adversity quotient. The description of theoretical learning models at this university can be shown in figure 1 .

Based on this description, it is common that the online PAI course learning model at its university is framed in a learning process that activates the three domains of learners, namely the assimilation trying to understanding the meaning of belief and faith; accommodation with rational-critical thinking process; and equilibration with a new understanding of religion formed in the context of real life. 


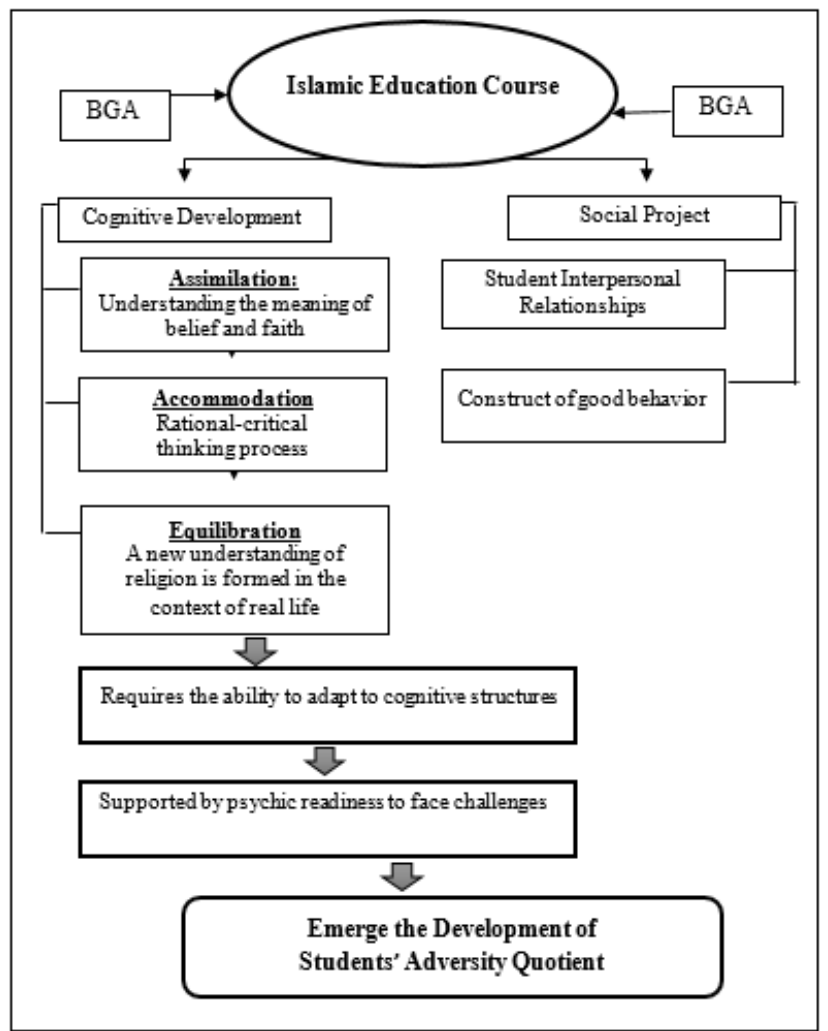

Fig. 1. Illustration of Theoretical Learning Model of PAI Course

\subsection{Students' adversity quotient in the context of PAI course learning model}

Stoltz, as one of the initiators of adversity quotient theory, emphasized the self-adversity abilities on four main components, namely control, ownership, reach, and endurance. This research found that the students' adversity quotient was developed through cognitive development and social project activities; a self-gratefulness is an indicator of adversity quotient of the students that appears to achieve the desired goals of their learning; while resilience is a form of students' adaptability to the PAI course challenges. These components help students to set the goals, monitor progress, evaluate the progress against logical standards, and prepare oneself to face the consequences of the realities occurred around the individual. So, the indicator of students' adversity quotient lies in the students' ability to manage their adversity abilities effectively through academic process (Parvathy, U., \& Praseeda, 2014), including the competence in the aspect of language mastery (Shyr \& Chen, 2018) to achieve the maximal learning goals (Wolters, 1998).

This research also found that students' activities on PAI course could improve students' ability to control themselves in the form of learning efficiency. The results of this study are in line with Murty's research, which revealed that online learning paradigm also experienced a shift from teacher-centric to learner-centric assessed by academics to be a complementary factor in realizing educational objectives. (Murty, B. V., \& Rao, 2019). Nowadays, the situations of online learning require an adaptive attitude of students towards the development of information technology (IT) as the important medium for online learning. Furthermore, this study found that Islamic education course had an urgent position to develop students' adversity quotient from multi-perspective elements, including developing the cognitive side of learners through assimilation, accommodation, and equilibration PAI learning activities. This finding reinforces the conclusion of Cigdem, which cocluded that the process of knowledge construction is an important factor in floating one's cognitive abilities, and it can be reached through assimilation, accommodation, and equilibration of new knowledge (Gunduz \& Hursen, 2015), or even social project activities developing students' psychological aspects at this university. In the form of developed students interest in learning, this study at the same time strengthened the students' spiritual intelligence (Lestari, 2020) or Borokhovski's (Borokhovski \& et al., 2018; Engin, 2017) thesis.

Apart from the ability to carry out learning efficiently, another characteristic that arises from a student's adversity quotient lies in an ability to construct and adapt to the environment that supports his or her learning process. For some individual learners, the transformation of the learning model from face-to-face (offline) to face-to-virtual (online) is a learning situation that is still unfamiliar; hence, it needs to be responded through some efforts to acquire a new knowledge, including students in this university who learn PAI course. In some ways, transformation towards online learning through LMS system activities forces students to have an ability to manage themselves to complete their learning goals. This is where the adversity quotient plays a significant role from the perspective of students.

One of the significant strategies that students must take to synergize with the distance learning system they are running is through an ability to adapt to the use of digital devices. In addition, online data-based information collection activities, as well as implicational factors for online communication, often become challenges for students (Blau et al., 2020). The strategy executed by the students in undergoing PAI course is to actively cooperate their interpersonal relationship with their team in social project. The existence of the team who guide the aspects of constructing good behavior indirectly fosters a strong pattern of resilient, persistent, sincere, and selfgratefulness and improves academic skills in PAI course. By doing so, with good resilience abilities, students will personally be helped in the management of the information they receive during the PAI course process through an online learning model.

These findings confirmed scientific research conducted by many previous educational experts, which showed that the development of adversity quotient is more found in students joining online learning compared to students undergoing the conventional learning processes, as shown by Yulanda (Yulanda, 2017), or Broadbent's research (Broadbent, 2017), including research on the relationship between the digital learning ecosystem and self-learning skills and digital literacy in students. (Lee et al., 2020). In a community of learning environments that have many new sources of knowledge for individuals, it will encourage the individual to develop their thinking skills so that they can receive this new knowledge.

\section{Results and discussion}

3.1 Online learning design of PAI course: upstream the development of students' adversity quotient.

Based on university's academic guide, PAI's learning model at this university positions its students as active students 
through two academic activities, namely cognitive development (assimilation, accommodation, equilibration) and social project. In addition, theoretical learning model is also delivered to students through online-based learning in asynchronous and synchronous platforms that are centered on the university's LMS system. In this context, the researcher analyzed various learning models used in the PAI course into two patterns, which have a complementary interactive relationship.

The first pattern refers to the contextualization of knowledge students learn in class with real-life activities in which the students encounter in the community or in the team. This can be analyzed from the theoretical learning model of PAI course manifested in the activities of social project. These academic activities provide an access for students to find a different tutor (i.e. their own friend in the classroom) who is competent in the field of understanding religious knowledge in different ideology and perspective. The tutor then plays a role in helping students to improve their understanding of religious knowledge that they have considered the same things. Active learning is carried out by students. It is evident from this activity that it leads to the increasing competence of religious knowledge and self-gratefulness in students. The contextualization of the learning referred to by the researchers lies in a complementary interactive relationship pattern between the knowledge students receive through learning in the classroom, and the acquisition of new knowledge and experience in terms of social project relationship from the team and the tutors accompanying the students' academic activities. On the other hand, social project in PAI course is also an arena for students to hone their cognitive abilities in understanding and analyzing the teaching materials in the form of slide presentations and learning videos uploaded by lecturers. This is where students' creativity is required to be able to study and analyze the themes of PAI course through their academic thoughts and views.

Second pattern is theoretical learning model implemented through asynchronous and synchronous learning platforms in LMS system. PAI course activities, which are contained in these two platforms, lead students to acquire Islamic knowledge that must be carried out by students actively. This active role can be seen through the responses that must be given by students to the process of stimulating a variety of knowledge conveyed by the lecturers in web system, especially when they get this knowledge through virtual learning media closely related to online learning designs, and intersects with the use of learning technology. In such situation, the responses shown by students determine the success of their online learning in the PAI course.

Based on this analyze, the researchers concluded that learning design of PAI course at this university could be considered as a manifestation of the university's theoretical learning model to develop students' adversity quotient through the following stages of learning that the students passed: First, Stimulation and Problem Identification. This stage is passed by students while undergoing learning in the LMS web system. Multivariate information as well as new knowledge contained in the LMS web system become a cognitive stimulus in which at the same time it forces students to sort and identify the difficulties, they experience in participating in learning activities in the learning system. This is conveyed by one of the students:

In my opinion, Virtual-Based Learning or VBL is one of the favorite features for lectures at university's LMS system.
Through VBL, I can learn by incorporating audiovisual media that I don't think is boring and makes it easier for me to understand the material. It is also effective because I can get a lot of information in a relatively short time. In addition, VBL is a new learning experience for me at this university.

Second one is Learning Problem-content Analysis. This stage is passed by students after they have succeeded in identifying academic problems encountered in PAI course. For example, the social project activity, which requires students to seek their tutors is a challenge and a difficulty that the students must respond to by finding solutions to these problems. As a result, the students have to start collecting data from the community around them, and choose a competent tutor to accompany them in the process of social project activities. The interaction that must be built by students during the tutor search process, directly or indirectly, will develop students' problemcontent analysis cognitive ability. In addition, students will learn to control themselves when identifying and analyzing the problem-themes of PAI course with their tutors. After the information collection stage has been passed, it continues at the third stage, that is information analyzing stage into the initial knowledge structure possessed by previous students.

The fourth one is Verification of Results that takes place when students have gone through the learning process, both theoretically in the classroom through the lectures system, and practically through social project activities which they carry out with assistance from their team and mentors. As a form of verification of learning outcomes, students send the process progress and learning outcomes by taking written tests, oral tests, and sending recorded video to lecturers who are teaching Islamic education course. The fifth one is Generalization. This stage is the peak of the learning design of PAI course at this university. The generalization stage is marked by the development of understanding as well as the increased quality of new knowledge of students in terms of their religious knowledge and skill. As a form of the written evaluation, the development of understanding and improvement of student skills can be observed through data on student learning outcomes, both in the form of written exams and in the form of social project practice assessments. Thus, the researcher visualized the learning design stages of PAI course into the following image:

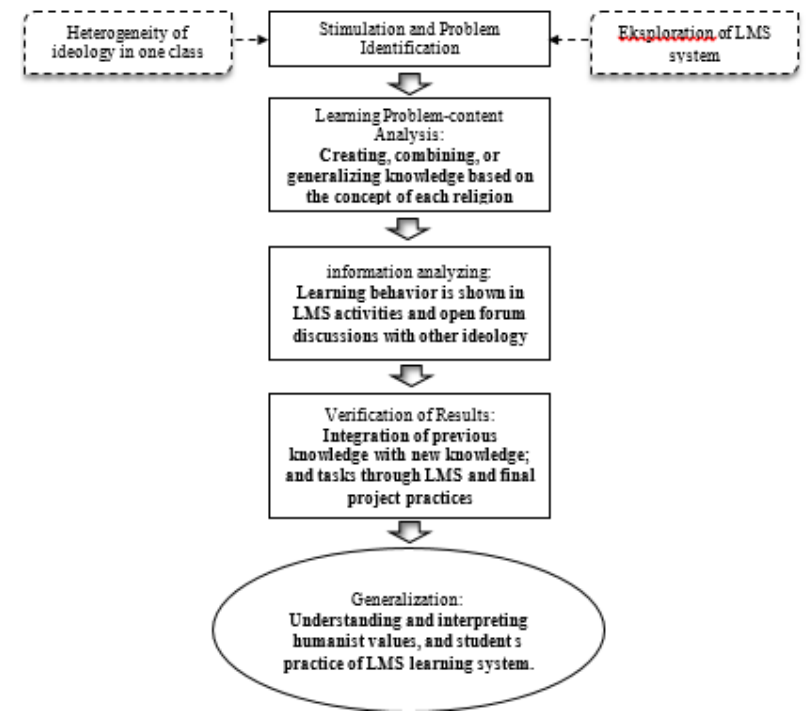

Fig. 2. Illustration of Learning Design Stages of PAI Course 
The learning design stages as shown in the figure refer to a roadmap for the learning design process in which the students taking PAI course at the university have to go through. It can be proven from the cognitive process that they have to go through in the form of problem identification and learning problem-content analysis that arises from social project and cognitive development. First stage (Stimulation and Problem Identification) and the second ones (Learning Problem-content Analysis) are the ability to exploit change (i.e. resilient, persistent). Next stages (Information Analyzing), the fourth (Verification of Results) and the five stages (Generalization) are the ability to adapt to change (i.e. adaptability, sincere, and self-gratefulness). These four entities that indirectly develop adversity quotient in students, as Stoltz's thesis.

These stages require students' awareness, knowledge, and control over their cognition. This is necessary for students to make them able to study all the new knowledge received in the PAI course process. The readiness of students' cognitive thinking to carry out the process of their adversity quotient has been pointed out in Dorji's research concluding that online academic process (Dorji \& Singh, 2019) needs to be developed as awareness from within oneself (Widiantie, R., \& Handayani, 2018) as an effort to solve academic problems faced by individuals through an online learning process. Thus, the authors can state that the learning design of PAI course implemented at this university leads to the development of students' adversity quotient and regulatory abilities through four main indicators, namely: resilient, persistent, sincere, and self-gratefulness.

\section{Conclusion}

The results of this study indicated that the learning design of PAI course at a university in Malang refers to a learning design stage with five learning processes, namely: Stimulation and Problem Identification; Learning Problemcontent Analysis; Information Analyzing; Verification of Results and Generalization. These stages lead to the development of students' adversity quotient as a form of increasing student competence. The results of this study reinforce the statement that the learning design can improve the competence of students, including students' adversity quotient. The learning model of PAI course that is encapsulated at this university can encourage students to become individuals who have resilience, persistence, sincerity, and self-gratefulness. The contribution of this research is crucial to the implementation of online Islamic education learning through a theoretical learning model that will lead to benefits in achieving educational targets more effectively.

\section{References}

Abuhassna, H., Al-Rahmi, W. M., Yahya, N., Zakaria, M. A. Z. M., Kosnin, A. B. M., \& Darwish, M. (2020). Development of a new model on utilizing online learning platforms to improve students' academic achievements and satisfaction. International Journal of Educational Technology in Higher Education, 17(1)

Adriyanto et al. (2020). Peningkatan Kompetensi Strategis Siswa melalui Model Pembelajaran Conceptual Understanding Procedures. Justek: Jurnal Sains Dan Teknologi, 2(1), 1-10.

Asy'ari, M., Ikhsan, M., \& Muhali, M. (2018). Apa Itu Metakognisi dan Mengapa Penting? Prosiding Seminar Nasional Lembaga Penelitian Dan Pendidikan (LPP) Mandala, 340-344.

Blau, I., Shamir-Inbal, T., \& Avdiel, O. (2020). How does the pedagogical design of a technology-enhanced collaborative academic course promote digital literacies, self-regulation, and perceived learning of students? Internet and Higher Education, 45(April).

Borokhovski, E., \& et al. (2018). Achievement and attitudes in technologysupported postsecondary education: Complexity of relationships through the lens of meta-analysis. Proceedings of EdMedia: World Conference on Educational Media and Technology, 1994-2003.

Broadbent, J. (2017). Comparing online and blended learner's self-regulated learning strategies and academic performance. Internet and Higher Education, 33(September), 24-32.

Carter, R. A., Rice, M., Yang, S., \& Jackson, H. A. (2020). Self-regulated learning in online learning environments: strategies for remote learning. Information and Learning Science, 121(5-6), 311-319.

Dinsmore, D. L., Alexander, P. A., \& Sandra M. Loughlin. (2008). Focusing the conceptual lens on metacognition, self-regulation, and selfregulated learning. Educational Psychology Review, 20(4), 391-409.

Dorji, R., \& Singh, D. K. (2019). Role of Adversity Quotient in Learning. International Journal of Education, 11(46229), 119-125.

Engin, M. (2017). Analysis of Students' Online Learning Readiness Based on Their Emotional Intelligence Level. Universal Journal of Educational Research, 5(12A), 32-40.

Gunduz, N., \& Hursen, C. (2015). Constructivism in Teaching and Learning; Content Analysis Evaluation. Procedia - Social and Behavioral Sciences, 191(392), 526-533.

Härkki, T., Vartiainen, H., Seitamaa-Hakkarainen, P., \& Hakkarainen, K. (2021). Co-teaching in non-linear projects: A contextualised model of co-teaching to support educational change. Teaching and Teacher Education, 97(XXXX), 1-14.

Hooshyar, D., Pedaste, M., Saks, K., Leijen, Ä., Bardone, E., \& Wang, M. (2020). Open learner models in supporting self-regulated learning in higher education: A systematic literature review. Computers and Education, 154(April), 1-19.

Jureynolds, \& Ying, Y. (2020). Design and Implementation of Internet-Based Flipped Classroom in the Introduction to Chinese Business Course at the Chinese Department of BINUS University. Journal of Physics: Conference Series, 1477(4), 1-6.

Landrum, B., Bannister, J., Garza, G., \& Rhame, S. (2020). A class of one: Students' satisfaction with online learning. Journal of Education for Business, 96(2), 82-88.

Lee, D., Watson, S. L., \& Watson, W. R. (2020). The Relationships Between Self-Efficacy, Task Value, and Self-Regulated Learning Strategies in Massive Open Online Courses. International Review of Research in Open and Distance Learning, 21(1), 1-22.

Lestari, S. (2020). Hubungan Kecerdasan Spiritual Terhadap Self Regulated Learning ( SRL) Pada Mahasiswa Fakultas Kedokteran Umum Universitas Malahayati Angkatan 2018. Anfusina: Journal of Psychology, 3(1), 85-96.

Li, S., Chen, G., Xing, W., Zheng, J., \& Xie, C. (2020). Longitudinal clustering of students' self-regulated learning behaviors in engineering design. Computers and Education, 153(November 2019), 103899.

Loeffler, S. N., Bohner, A., Stumpp, J., Limberger, M. F., \& Gidion, G. (2019). Investigating and fostering self-regulated learning in higher education using interactive ambulatory assessment. Learning and Individual Differences, 71(February), 43-57.

Louca, E. P. (2003). Metacognition and Theory of Mind. Cambridge Scholars Publishing.

Miles, M. B., Huberman, A. M., \& Saldana, J. (2014). Qualitative Data Analysis A Methods Sourcebook (3rd ed.). SAGE Publications.

Mulianti et al. (2018). Kompetensi Lulusan Pendidikan Vokasi: Peran Faktor dan Indikator yang Berpengaruh. Prosiding Seminar Nasional Asosiasi Pendidikan Teknologi Dan Kejuruan Indonesia (APTEKINDO) 2018, 31-46.

Murty, B. V., \& Rao, K. N. (2019). Digital Pedagogy-An Opportunity or a Threat? Proceedings of International Conference on Digital Pedagogies (ICDP), 1-5.

Parvathy, U., \& Praseeda, M. (2014). Relationship between Adversity Quotient ${ }^{\circledR}$ and Academic Problems among Student Teachers. Journal of Humanities and Social Science, 19(11), 23-26.

Rachmawati, R. (2018). Analisis Keterkaitan Standar Kompetensi Lulusan (SKL), Kompetensi Inti (KI), Dan Kompetensi Dasar (KD) Dalam Implementasi Kurikulum 2013. Tatar Pasundan: Jurnal Diklat Keagamaan, 12(34), 231-239.

Undang-Undang Republik Indonesia Nomor 20 Tahun 2003 tentang Sistem Pendidikan Nasional, Pub. L. No. 4301, Public Law of Republic of Indonesia 19 (2003).

Shyr, W. J., \& Chen, C. H. (2018). Designing a technology-enhanced flipped learning system to facilitate students' self-regulation and performance. Journal of Computer Assisted Learning, 34(1), 53-62. 
Stoltz, P. G. (1997). Adversity Quotient: Turning Obstacles into Opportunities. John Wiley \& Sons.

Vinas, D. K. D., \& Aquino-Malabanan, M. G. (2015). Adversity quotient and coping strategies of college students in Lyceum of the Philippines University. Asia Pacific Journal of Education, Arts and Sciences, 2(3), 68-72.

Wardani. (2019). Pengaruh kecerdasan adversitas dan kecerdasan emosional melalui model inkuiri sosial terhadap keterampilan sosial siswa. Urnal Teori Dan Praksis Pembelajaran IPS, 4(2), 66-73.

Waschull, S. B. (2018). Improving Developmental Education Reform in Florida. In Promising Practices in Developmental Education (Vol. 182 Issue Summer 2018, pp. 75-83). New Directions for Community Colleges.
Widiantie, R., \& Handayani, H. (2018). Kesadaran Metakognisi dan Keterampilan Memecahkan Masalah Mahasiswa melalui Pembelajaran Berbasis Masalah dengan Penugasan Individu. Quagga: Jurnal Pendidikan Dan Biologi, 10(1), 56-62.

Wolters, C. A. (1998). Self-Regulated Learning and College Student Regulation of Motivational. Journal of Educational Psychology, 80(3), 284-290.

Wolters, C. A., Pintrich, P. R., \& Karabenick, S. A. (2005). "Assessing Academic Self-Regulated Learning,." In What Do Children Need to Flourish? (pp. 251-270). Springer.

Yulanda, N. (2017). Pentingnya Self Regulated Learning Bagi Peserta Didik Dalam Penggunaan Gadget. Research and Development Journal of Education, 3(2), 164-171. 